\title{
Diversity and distribution of Cirripedia from Gujarat Coast, India
}

\author{
H. H. Parmar ${ }^{1 *}$, D. M. Joshi ${ }^{2}$, H. Salvi ${ }^{3}$, R. D. Kamboj ${ }^{4}$ \\ ${ }^{1,2,3,4}$ GEER Foundation, Indroda Nature Park, Gandhinagar, India \\ *Corresponding Author: heena.parmar.hp9@gmail.com, Mob. 7573020468
}

Available online at: www.isroset.org

Received: 23/Sept/2018, Accepted: 17/Oct/2018, Online: 31/Oct/2018

\begin{abstract}
Compared to other taxons of crustacea, limited literature is available on the diversity of Infraclass Cirripedia (Barnacles), as they are not much studied from the taxonomical point of view. The present study describes a total of 7 species of Intertidal cirripedia from Gujarat coast which includes the actual study and review. The highest species diversity was recorded from the Saurashtra coast bearing rocky intertidal areas, the highly supportive habitat for their attachment. The most common species observed were Tetraclita squamosa rufotincta, Amphibalanus amphitrite, Chthamalus stellatus and Balanus crenatus found flourishing on rocky shore with high density.
\end{abstract}

Keywords: Cirripedia, Crustaceans, Barnacle, Saurashtra, Intertidal

\section{INTRODUCTION}

Crustaceans are the most important benthic Arthropods inhabiting aquatic ecosystem, playing an important role in balancing the ecosystem. These are economically important as they are used for human consumption as well. These include, crabs, prawns, shrimps, squilla, crayfishes, lobsters, barnacles etc. The estimated crustacean diversity is believed to be approximately 52,000 species which leads them to be on the fourth position next to insects, molluscs and chelicerates, in terms of overall species diversity [1]. The most intensely studied group among different taxons of crustacea are the true crabs (Infra-order Brachyura) consisting of 6793 species and subspecies, 1271 genera and subgenera and 93 families belonging to order Decapoda, worldwide [2]. In India around 2934 species have been described so far, contributing $94.85 \%$ of the global biodiversity [3]. Different studies on Gujarat coast contributes a total of 188 species of Crustaceans belonging to 53 families and 8 orders [4],[5],[6],[7],[8],[9],[10],[11],[12],[13].

The crustacean Cyprus larvae normally attach to hard substratum and metamorphose in adult sessile barnacles. They inhabit mostly in marine environment while some species are capable to live in low salinity and found in estuaries [14]. They are very successful group today having 1445 living species as well as good abundance [15]. A total of 280 species of thoracic barnacles have been found [16], [17], [18], but only 48 species have been reported so far from the intertidal zones of India [18]. A few studies have been carried out to know their abundance from the intertidal area due to obstacles in specimen collection. Most of the studies on barnacles conducted so far have highlighted their interesting reproductive relationships. Merely a few species of barnacles are economically important. It may be due to smaller size of individuals, in spite of wide range of varieties on global scale [19], can also be considered as one of the reasons for less exploration.

They have long caused problems as fouling organisms on ships and docks in fishing industry. The barnacle cements are also used in dentistry [20], [21], [22]. In countries like Spain and Portugal, barnacles are also used as food and in Japan certain species are cultivated for fertilizers [15]. Apart from these scientists are also trying to trace migratory pattern of hosts on which they grow [22].

\section{MATERIALS AND METHODS}

The present study was carried out from 2016 to 2017 in the intertidal areas of Gujarat coast divided into three major parts viz., the Gulf of Kachchh, the Gulf of Khambhat and the Saurashtra region under the Integrated Coastal Zone Management (ICZM) Project. The survey was carried out in two ways: line transects method along with quadrates at regular interval and Opportunistic observation/ whole area search. Each transect was of $100 \mathrm{~m}$ with quadrates laid at a regular interval of $20 \mathrm{~m}$ in the intertidal area of different habitats of Gujarat coast during the small temporal window of low tide. Also collection of species was carried out from the non-protected areas of Gujarat coast. The collected specimens were identified by some of the published literatures [23], [24], [25]. The classification was adopted from the World Register of Marine Species website [26]. Biodiversity indices such as species richness, Dominance, Simpson, Shannon and Evenness were calculated with the 
help of PAST software while Density and abundance were performed for quantitative analysis [27].

\section{RESULTS AND DISCUSSION}

The present study describes a total of 7 species of barnacles from Gujarat coast, most of which are well distributed in the intertidal areas of Saurashtra coast as having rocky shore throughout. There are sporadic reports available for diversity of barnacles, still very few information available and need extensive study. Tetraclita squamosa rufotincta, Amphibalanus amphitrite, Chthamalus stellatus and Balanus crenatus were found to be the common species of barnacles from the Suarashtra coast and the Gulf of Kachchh areas.

Table 1: Diversity Indices for barnacle diversity

\begin{tabular}{|c|l|l|l|l|l|l|l|l|}
\hline $\begin{array}{l}\text { Diversity } \\
\text { Indices }\end{array}$ & $\mathbf{1}$ & $\mathbf{2}$ & $\mathbf{3}$ & $\mathbf{4}$ & $\mathbf{5}$ & $\mathbf{6}$ & $\mathbf{7}$ & $\mathbf{8}$ \\
\hline Richness & 3 & 2 & 1 & 2 & 2 & 1 & 1 & 1 \\
\hline Dominance & 0.50 & 0.51 & 1 & 1 & 1 & 1 & 1 & 1 \\
\hline Simpson & 0.49 & 0.48 & 0 & 0 & 0 & 0 & 0 & 0 \\
\hline Shannon & 0.69 & 0.68 & 0 & 0 & 0 & 0 & 0 & 0 \\
\hline Evenness_ & 0.99 & 0.98 & 1 & 1 & 1 & 1 & 1 & 1 \\
\hline
\end{tabular}

(1-Sutrapada, 2 - Harsiddh, 3 - Jhanjmer, 4 - Gosa, 5 - Poshitra, 6 Dwarka, 7 - Okha, 8 - Sikka) rufotincta have comparatively low abundance but have highest density among the other common species of the study area. The barnacle Tetraclita squamosa rufotincta was recorded only from Sutrapada and is found in very big colony covering a huge area and favoured this highest density as compared to other species. In the case of Amphibalanus amphitrite, some similarities were observed in abundance and density which ultimately conclude that the species is equally distributed among all the zones of intertidal areas.

Table 2: Species checklist of Barnacles

\begin{tabular}{|c|c|c|c|}
\hline SN & Family & Species & References \\
\hline 1 & Balanidae & $\begin{array}{l}\text { Amphibalanus } \\
\text { Amphitrite (Darwin, } \\
\text { 1854) }\end{array}$ & $\begin{array}{l}\text { Singh } \text { et.al.,2004; } \\
\text { Trivedi } \text { et al. } 2015 \text {; } \\
\text { present study }\end{array}$ \\
\hline 2 & Balanidae & $\begin{array}{l}\text { Megabalanus } \\
\text { tintinnabulum } \\
\text { (Linnaeus, 1758) }\end{array}$ & $\begin{array}{l}\text { Singh et.al.,2004; } \\
\text { Trivedi et al. } 2015\end{array}$ \\
\hline 3 & Chthamalidae & $\begin{array}{l}\text { Chthamalus stellatus } \\
\text { (Poli, 1791) }\end{array}$ & Present study \\
\hline 4 & Balanidae & $\begin{array}{l}\text { Balanus crenatus } \\
\text { Bruguière, } 1789\end{array}$ & Present study \\
\hline 5 & Tetraclitidae & $\begin{array}{l}\text { Tetraclita squamosa } \\
\text { rufotincta (Bruguière, } \\
1789 \text { ) }\end{array}$ & $\begin{array}{l}\text { Daniel, 1972; } \\
\text { Fernando, 2006; } \\
\text { Present study }\end{array}$ \\
\hline 6 & Tetraclitidae & $\begin{array}{l}\text { Tetraclitella } \\
\text { purpurascens (Wood), } \\
1815\end{array}$ & $\begin{array}{l}\text { Fernando, 2006; } \\
\text { Present study }\end{array}$ \\
\hline 7 & Lepadidae & $\begin{array}{l}\text { Lepas (Anatifa) } \\
\text { anserifera Linnaeus, } \\
1767\end{array}$ & Present study \\
\hline
\end{tabular}

The highest species richness was observed in Sutrapada which represents three species of barnacles. The highest Shannon diversity index was found in Sutrapada (0.6892) followed by Harsidh (0.6775), indicating high species as each site shows 2 species. The evenness value for Sutrapada and Harsidh was found nearer to 1 so it can be concluded that species found in those areas are evenly distributed.

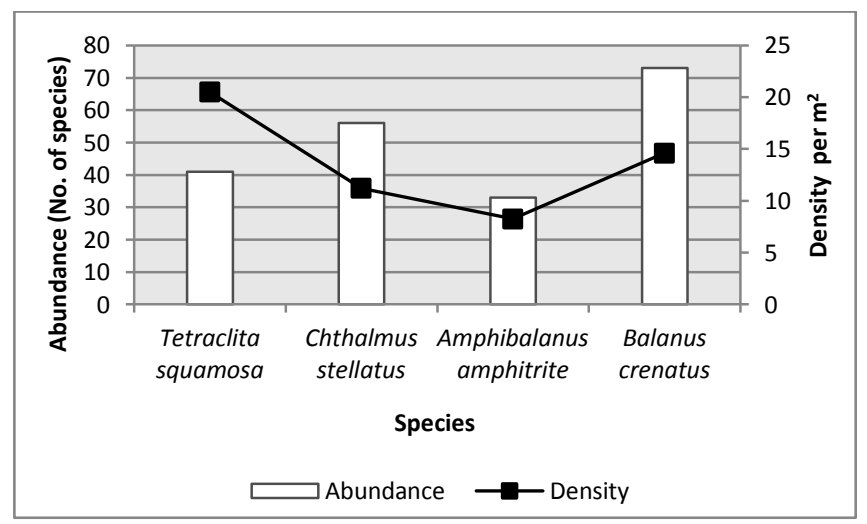

Figure 1: Abundance and density of most common species of Gujarat coast

The graph (fig.1) clearly reveals that Balanus crenatus has the highest abundance among all species but its density was found lower. It means the species are sparsely distributed in the study area. On the other hand, Tetraclita squamosa
1) Balanus crenatus: The individuals were found having acute carinal end and blunted rostral end creating a pentagonal shape. Valves have distinctive form. Scutum was found with strong growth ridges. There were total 6 wallplates having ridged surface. Both the sides of carinal plate were covered by lateral plates, the two lateral plates found to have one alae (side covered by adjacent plate) and one radii (side covering the adjacent plate) while the rostral plate was found to cover the lateral plates on both sides. The open valve barnacles were found to have crenate rim of the aperture.

Habitat: Rocky shore

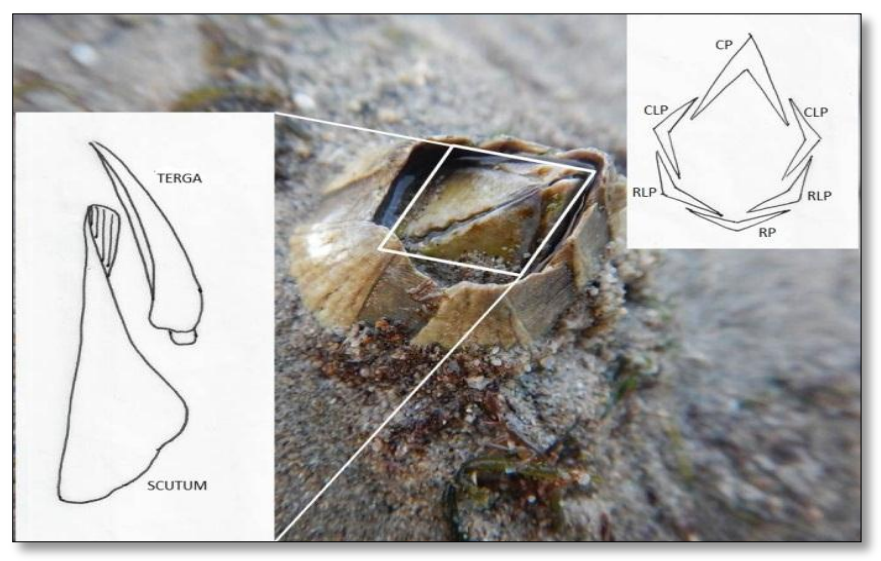

Figure 2: Balanus Crenatus

(CP-Carinal Plate; CLP-Carino-lateral Plate, RLP Rosstrolateral Plale; RP-Rostral Plate) 
2) Chthamalus stellatus: Some of the individuals were found having oval while some having kite shaped aperture. A very few growth-lines were found on the edge of the scuta towards rostral plate. The barnacles generally possess 6 lateral plates but were found distinct only in few juvenile forms while in older individuals they were found to be fused.

Habitat: Rocky shore

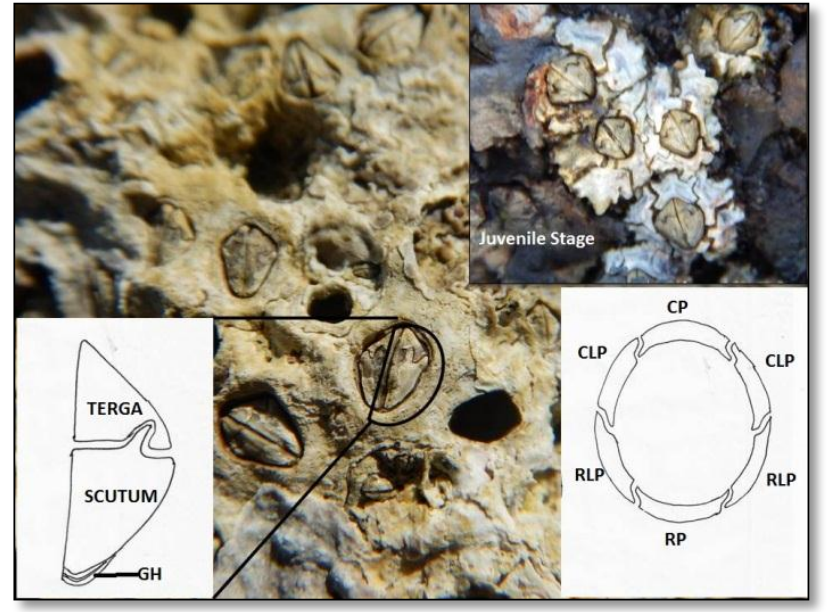

Figure 3: Balanus stellatus

(CP-Carinal Plate; CLP - Carino-lateral Plate, RLP Rosstrolateral Plale; RP-Rostral Plate, GL-Growth Lines)

3) Tetraclitella purpurescens.: The individuals were found having diamond shaped operculum having distinct pairs of terga and scutum valves. Scutum valves found to have strong growth ridges. The operculum was guarded by four wall plates a paired lateral, one carinal and one rostral. Both the sides of carinal plate were covered by lateral plates. The lateral plates have one alae and one radii while both sides of rostral plates cover the lateral plates.

Habitat: Rocky shore

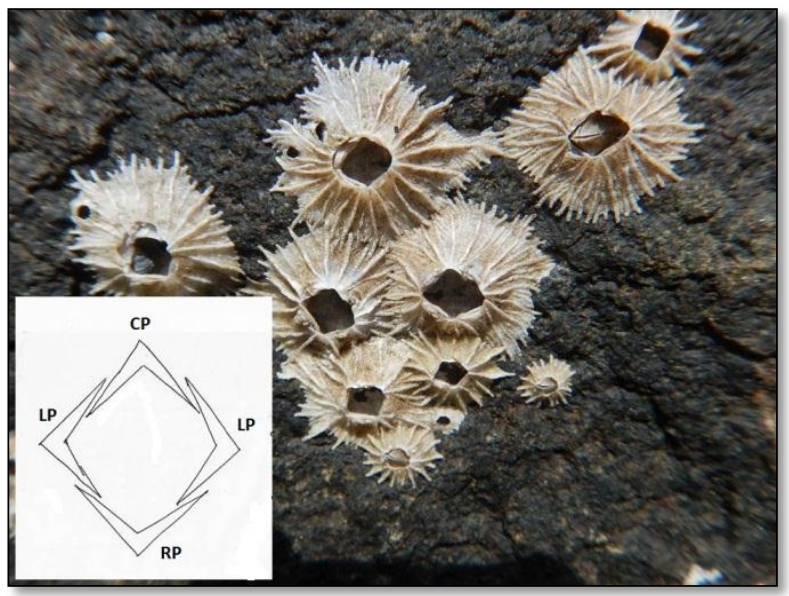

Figure 4: Tetraclitella purpurescens (CP-Carinal Plate; LP-Lateral Plate, RP-Rostral Plate)

4) Tetraclita squamosa rufotincta: The individuals were found having pink coloured conical shell made up of four thick plates, i.e., carinal plate, rostral plate and two lateral plates. The plates were almost fused together and were not distinguishable. The plates were found having number of ridges along with the rows of pores. The operculum was found almost irregular in many individuals while some was found with diamond or oval in shape.

Habitat: Shaded rocky substratum

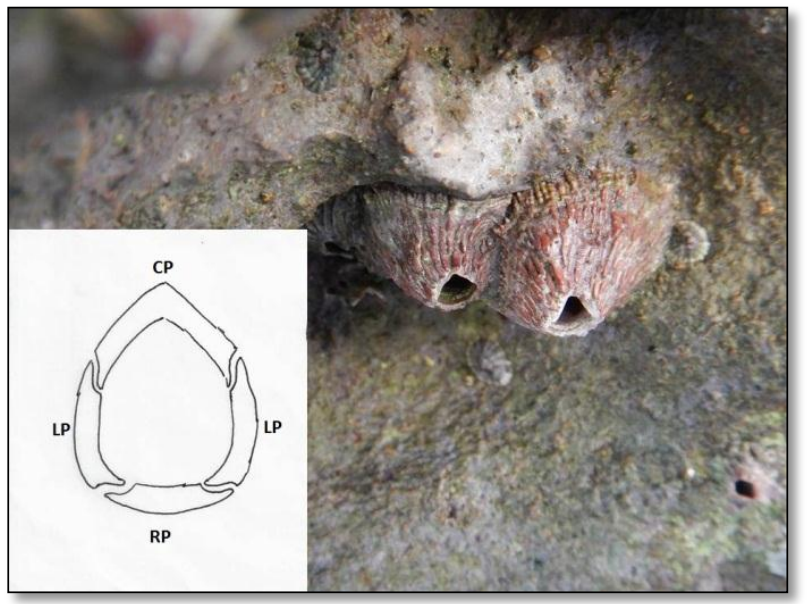

Figure 5: Tetraclita squamosa rufotincta

(CP-Carinal Plate; LP-Lateral Plate, RP-Rostral Plate)

5) Amphibalanus amphitrite: Same as Balanus crenatus, the 6 wall plates consists of carinal plate having both the sides covered by lateral plates, the two lateral plates having one alae one radii while the rostral plate was found to cover the lateral plates on both sides. Pale and white coloured wall plates with purplish brown stripes. Shape was depressed conical. Operculum having rhomboid shape. Scutum with prominent growth ridges. The colour of scutum having tinge of mauve.

Habitat: Coral reef and Rocky shore

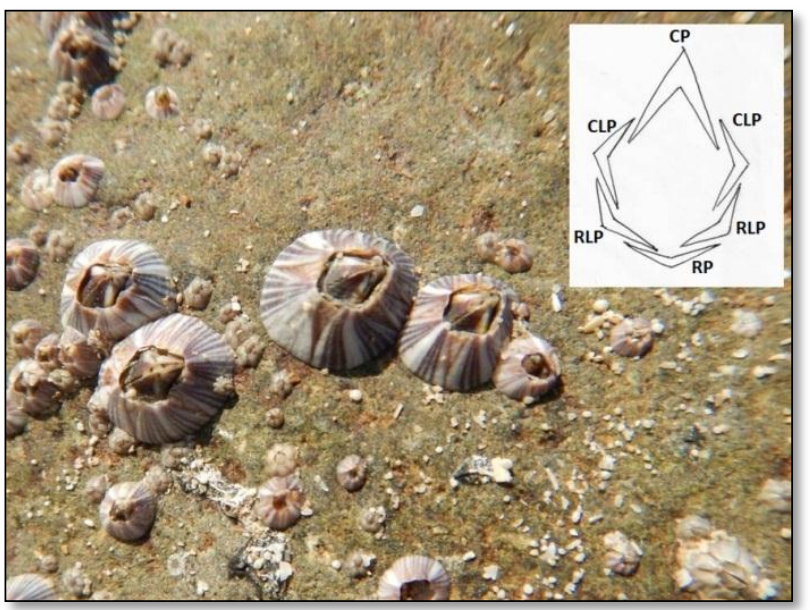

Figure 6: Amphibalanus amphitrite

(CP-Carinal Plate; CLP - Carino-lateral Plate, RLPRostrolateral Plale; RP-Rostral Plate) 
6) Lepas (Anatifa) anserifera: Individual was found having flexible peduncle. Uppermost part of the peduncle was orange. Capitulum was found more elongated compared to its breadth. It was found having five valves, paired Scuta, paired Terga and one Carina. Occludent margin of scutum was more arched.

Habitat: Hard substratum such as shells, artificial substratum such as plastics, wood etc.

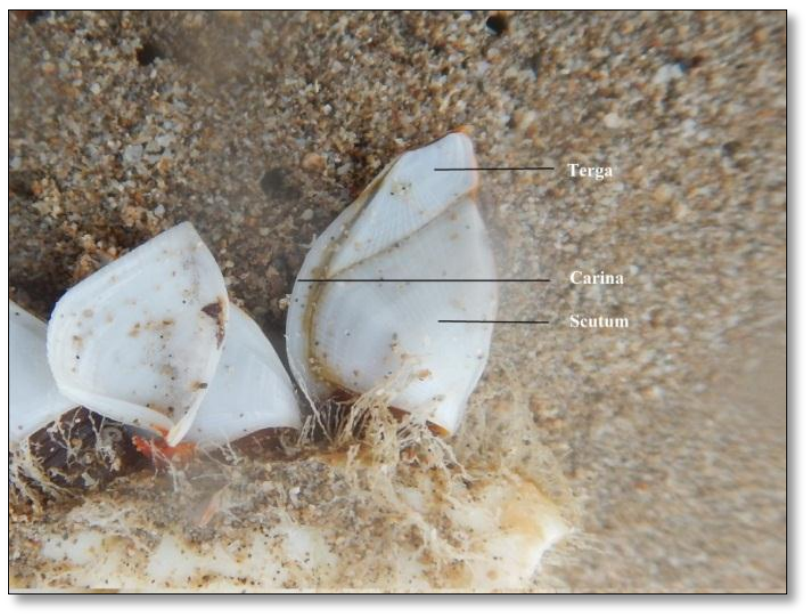

Figure 6: Lepas (Anatifa) anserifera

\section{CONCLUSION}

A total of 7 species of barnacles have been identified from the intertidal region of Gujarat coast. Most of the species diversity was recorded from the rocky coast of Saurashtra region followed by the Gulf of Kachchh and the least species diversity was from the Gulf of Khambhat and the south Gujarat coast. Amphibalanus amphitrite was found equally distributed species among different zonation of intertidal areas

\section{ACKNOWLEDGEMENT}

Authors are highly grateful to the World Bank, MoEF \& CCGoI, SICOM-NPMU and Gujarat Ecological Commission (GEC-SPMU) for providing financial support under the Integrated Coastal Zone Management Project under which the research was carried out. Authors also thank the Department of Forests-Government of Gujarat and Marine National Park \& Sanctuary for granting permission to carry out this research. Authors also like to thank Mr. Divyarajsinh Jadeja and Ms. Shuchi Bhatt for successfully carrying out field work and photo-documentations of species.

\section{Author Contribution}

The Manuscript was prepared by Heena Parmar, Devanshi Joshi and R. D. Kamboj. Species identification was carried out by Heena Parmar and Devanshi Joshi. Analysis of the study was carried out by Heena Parmar and Devanshi Joshi. Methodology development and overall conduction of field works were managed by Devanshi Joshi and Harshad Salvi.

\section{References}

[1] J. W. Martin, G. E. Devis, "An Updated Classification of the Recent Crustacea," National History Museum of Los Angeles County, Los Angele County, Californea, 2002; No.39 pp. 124.

[2] P. K. L. Ng, D. Guinot, P. J. F. Davie, "Systema Brachyurum: An annoted checklist of extant brachyuran crabs of the world," The Ruffles Bulletin of Zoology, Vol. 17, pp. 1 - 286, 2008.

[3] K. Venkataraman, M. Wafar, "Coastal Biodiversity of India," Indian Journal of Marine Science, Vol. 34 No. 1, pp. 57 - 75, 2005.

[4] P. C. George, M. J. George, P. V. Rao,"Metapenaeus kuchensis sp. Nov., a penaeid prawn from the Gulf of Kachchh," Journal of Marine boilogical Association, Vol. 5, No. 2, pp. 284-288, 1963.

[5] H. S. Singh, C. N. Pandey, P. Yennawar, R. J. Asari, B. H.Patel, K. Tatu, B. R. Raval, "The Marine Natinal Park and Sanctuary in the Gulf of Kachchh (A comprehensive study on biodiversity and management issues)", pp.161-178. 2004.

[6] D. Parasharya, G. Padte, "Status of scleractinian corals of Narara reef in the Gulf of Kachchh, western India," Jalplavit, Vol 4 No. 3, pp. $49-59,2013$.

[7] M. K. Dev Roy, "Diversity and distribution of marine brachyuran crab communities inhabiting west coast of India" in "Ecology and Conservation of Tropical Marine Faunal Communities" Part 1. (edt. K. Venkatraman, C. Sivaperuman and C. Raghunathan) Springer Berlin Heidelberg. pp 147 - 169, 2013.

[8] I. B. Beleem, J. S. Yogesh Kumar, Ch. Satyanarayana, K. Venkataraman, and R. D. Kamboj, "Distribution of Marine Crabs from the Marine National Park, Gulf of Kachchh," Scholars Academic Journal of Biosciences. Vol. 2, No. 7, pp. 419-427, 2014.

[9] Shukla, M. L., (2014). A comparative study of macro faunal community of natural and restored mangrove sites between Mahi and Dhadhar River Estuaries of Gulf of Khambhat. PhD thesis, The M. S. University of Baroda Vadodara. WTI, 2014

[10] D. J. Trivedi, J. N. Trivedi, G. M. Soni, B. D. Purohit, K. D. Vachhrajani, "Crustacean fauna of Gujarat state of India: A Review," Electronic Journal of Environmental Science. Vol. 8, pp. 23-31, 2015.

[11] J. Trivedi, K. Vachchhrajani, "On new record of Pagurus kulkarni Sankolli, 1962 (Crustacea: Anomura: Paguridae) from Gujarat, India," International Journal of Fisheries and Aquatic Studies, Vol. 4 No. 2, pp. 183 - 185, 2016.

[12] D. Jhala, S. B. Munjpara, J. Joshi, K. Joshi, S. S. Chettiar, " Special distribution of intertidal hermit crabs (Decapod: Anomura) togather with gastropod shell availability and utilization pattern on the southern coast of Gulf of Kachchh, Gujarat, India," Indian Journal of Life science Vol. 6 No. 1, pp. 77- 85, 2017.

[13] J. Arenas, “ Distribución de Elminius kingii Gray (Cirripedia) en el estuario del río Valdivia. Beiträge Zur Neotropical Fauna Vol. 6, No. 3, pp. 199-206. 1971 in D. A. Lopez, B. A. Lopez, C. K. Pham, E. J. Isidro, "Potency of Barnacles in aquaculture industry In: Muchlisin Z (ed). Aquaculture, Chapter 15, pp.295316, 2012.

[14] W. A. Newman, D. P. Abbott, (1980) "Cirripedia: the barnacles,"

[15] H. G. Stubbings, "Cirripedia”,John Murray Expedition 1933 1934, Scientific Reports, Vol. 4, pp. 1 - 70, 1936

[16] C. A. Nilsson-Cantell, "Cirripeds from the Indian Ocean in the collection of the Indian Museum, Culcutta, Memoires of Indian Museum, Vol. 93, pp. 1-366, 1938

[17] Daniel, A. "Marine intertidal barnacles in the Indian Ocean Proceedings of the Indian National Science", Academy-Part B, Vol. 38, No. 3-4, pp. 179-182 Available at http://www.new.dli.ernet.in/rawdataupload/upload/insa/INSA_1/2 0005b7c_179.pdf, 1972. 
[18] Anon, "Science and the citizens: Barnacle cement", Sci. Amer., pp. 219, 1968

[19] D. A. López., B. A. López, C. K. Pham, and E. J. Isidro. "Potency of barnacle in aquaculture industry." Aquaculture. InTech, 2012.

[20] R. S. Manly, "Adhesion in biological systems, New York Academic Press, pp.302, 1970;

[21] G. Walker, "The biochemical composition of the cement of two barnacle species, Balanus hameri and Balanus crenatus, Journal of Marine Biodiversity Association, U.K., Vol. 52, pp. 429 - 436, 1972

[22] J. S. Killingley, M. Lutcavage, "Loggerhead turtle movement reconstructed from 18-0 and 13-C profiles from commensal barnacle shell," East Coast. Shelf. Science Vol. 16 pp. 345 - 349, 1983.

[23] A. Daniel, P. K. Chakrabarti, "Notes on a collection of Barnacles from the east coast of India," Journal of Bombay Natural History Society, Vol. 63, No. 3, pp. $772-776,1966$.

[24] C. Darwin, "A monograph on the subclass Cirripedia (Balanidae)" Part 1, Printed for the Ray Society, London. pp.684, 1851.

[25] C. Darwin, "A monograph on the subclass Cirripedia (Lepadidae)” Part 2, Printed for the Ray Society, London. pp.418, 1854

[26] Society for the Management of European Biodiversity Data, "World Register of Marine Species" (WoRMS) Available at http://www.marinespecies.org, 2009.

[27] E. P. Odum, G.W. Barrett, "Fundamentles of Ecology Thomson Brooks/Cole, 2005.

\section{AUTHORS PROFILE}

Ms. Heena Parmar pursued her Bachelor's and Masters' degree in Zoology subject from VNSGU, Surat and MSU, Baroda respectively in the year 2011 \& 2013. She is currently working as Junior Research Fellow in Gujarat Ecological Education and Research (GEER) Foundation, Gandhinagar since 2014. Being on the initial stage, she has published 3 research papers in reputed national \& international journals. The work carried out by her is mainly focused on biodiversity of coastal ecosystems

Dr. Devanshi Joshi is presently working as research associate at Gujarat Ecological Education and Research (GEER) Foundation. She has completed her Ph.D. from MSU, Baroda on the impact of climate change on coral and coral reefs. She has been in the field of marine biodiversity, ecology, climate change and paleontological research since 2009. She has published 8 research papers, 4 reports and several popular articles.

Dr. Harshad Salvi, has done his Ph.D. from HNGU, Patan, was actively involved in a number of biodiversity of Protected Areas (Pas) at Gujarat State related to plant diversity as well as pollination biology \& reproductive ecology of rare mangrove species studies as scientist in GEER Foundation. He has over 18 years of research experience in

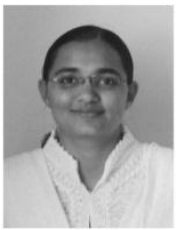
coastal, corals, grassland and forest ecosystems of Gujarat State and has published 12 research Papers. Presently he is serving as Assistant professor and Head, Botany Department, Government Science College, Songadh, Tapi, Gujarat.
Mr. R. D. Kamboj is an Indian Forest Services Officer of Gujarat cadre (1986 batch) of the rank of Additional Principal Chief Conservator of Forests. He holds post graduate degree in Agriculture from Haryana Agriculture University, Hisar \& in Forestry from Indira Gandhi National Forest Academy, Dehradun. He has served in various positions in Gujarat Forest Department for last 32 years. He has published more than 60 research papers and has written Working Plans/ Management Plans for various forest divisions including Gir National Park \& Sanctuary. Presently he is serving as Director, Gujarat Ecological Education and Research (GEER) Foundation, Gandhinagar. 